Task 45 Large Systems

ESCo services, best practise example:

Caixa Geral de Depósitos, Lisbon, Portugal

IEA-SHC TECH SHEET 45.C.2.2A, page 1 of 7

Subject:

ESCo services, best practise example

Description:

Example of Caixa Geral de Depósitos, Lisbon, Portugal

Date:

April 2015

Authors:

Sabine Putz, S.O.L.I.D. (s.putz@solid.at)

Download possible at:

http://task45.iea-shc.org/fact-sheets

\title{
Contents
}

Contents

Introduction 2

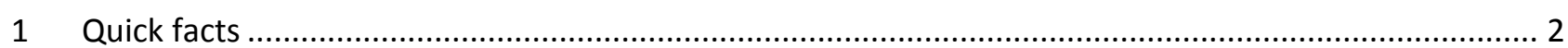

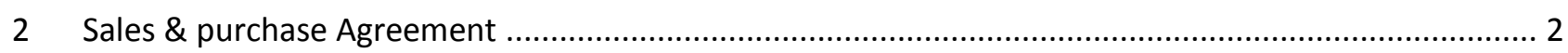

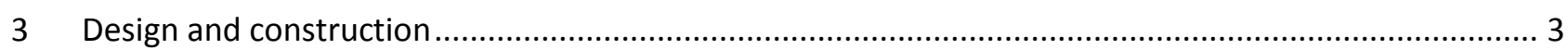

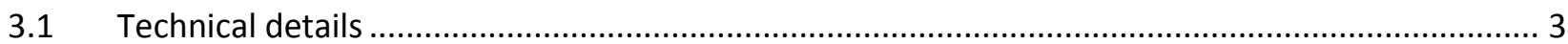

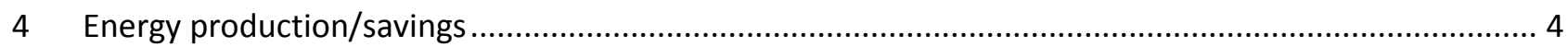

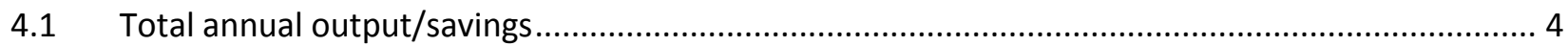

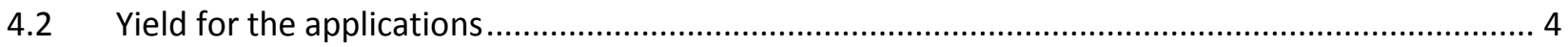

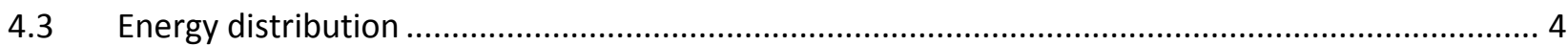

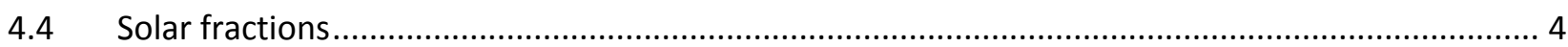

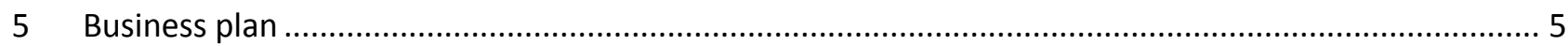

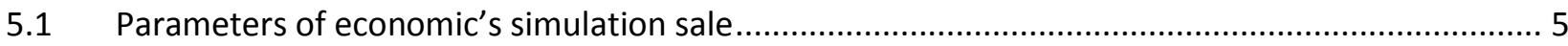

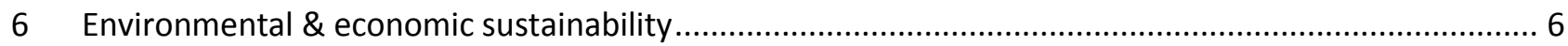

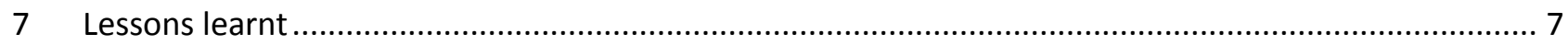

\section{S Caixa Geral}


ESCo services, best practise example:

\section{Caixa Geral de Depósitos, Lisbon, Portugal}

IEA-SHC TECH SHEET 45.C.2.2A, page 2 of 7

\section{Introduction}

In Lisbon a large office building of the bank Caixa Geral de Depósitos (CGD) are supported by solar heat and cold. The collector area is installed in roof of the office building. The office building has 17 floors with an office space of $100,000 \mathrm{~m}^{2}$. During the working time 6,000 employed persons are permanently in the building. The generated energy is used to power an absorption chiller. Furthermore, the energy is used for the reheating system of the ventilation appliances as well as contributing to the heating of hot water.

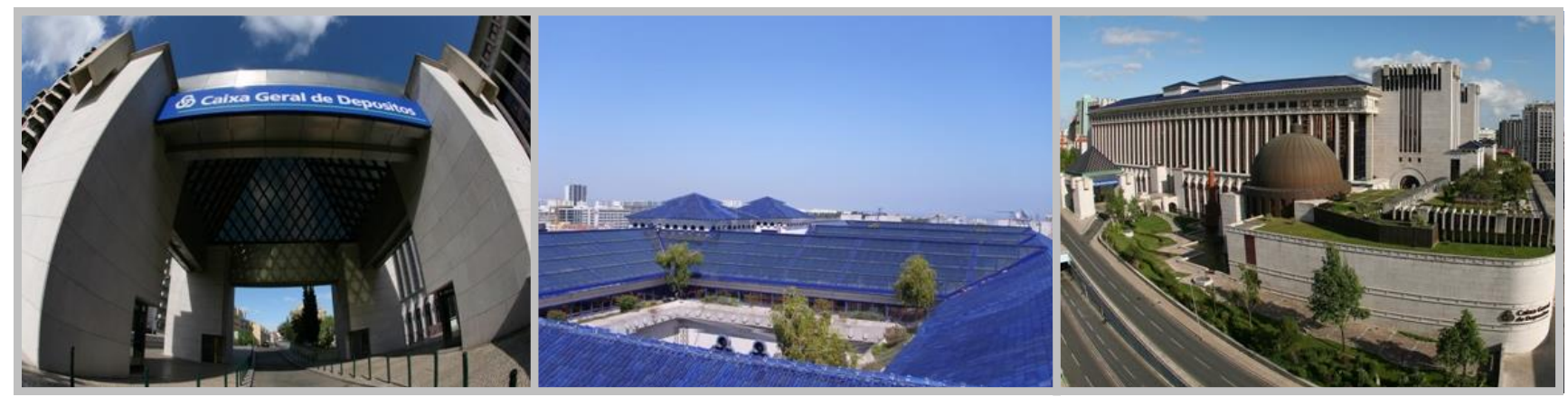

Figure 1. Pictures of the Caixa Geral de Depósitos installation

\section{Quick facts}

$\begin{array}{ll}\text { LOCATION: } & \text { Rua Arco do Cego, Piso 1; Lisbon Portugal } \\ \text { PLANT SIZE: } & 1,579 \text { sqm } \\ \text { TECHNOLOGY/RES: } & \text { Solar thermal HT collectors } \\ \text { SITE OWNERSHIP: } & \text { Caixa Geral de Depósitos } \\ \text { INVESTOR: } & \text { Caixa Geral de Depósitos } \\ \text { PROJECT COST: } & 1.04 \text { Mio } € \\ \text { State grants: } & 0 \% \\ \text { KEY PARTNERS: } & \text { S.O.L.I.D. GmbH (Desing \& Installation), Energia de Portugal (EdP) } \\ \text { CURRENT STATUS: } & \text { Operational } \\ \text { Installation: } & 1^{\text {th }} \text { QT 2008 }\end{array}$

\section{Sales \& purchase Agreement}

On the one side, CGD wished to install an economical RES to save energy, on the other side the architecture and appearance of the building had to be considered. Because of the location, the only available useful area is the roof of the building. The design of the collectors could be optimal combined with the existing blue tile roof. With the integration of the system, the existing energy distribution system has been optimized, and further energy savings achieved.

Thanks to the system app. $45 \%$ of the domestic hot water demand, $15 \%$ of reheating and $8 \%$ of the cold demand can be covered with this solar thermal system. 
ESCo services, best practise example:

\section{Caixa Geral de Depósitos, Lisbon, Portugal}

IEA-SHC TECH SHEET 45.C.2.2A, page 3 of 7

\section{Design and construction}

The solar energy is for building cooling and air-conditioning in the CGD building, in the months of April to September. Extra thermal energy from the plant may also be used to heat up the water coming from the existing $100 \mathrm{~m}^{3}$ tanks in the basement and to replace the electric energy used by the heat pumps to cover the heat needs for DHW and reheating the air. The solar energy is used for heating purposes mainly in the months of October to March. The energy output and current system data can be displayed on a monitor in the CGD offices as well as online, adding visibility and control of the energy output to the solar solution.

Control priority: 1. DHW, 2. reheating, 3. cooling

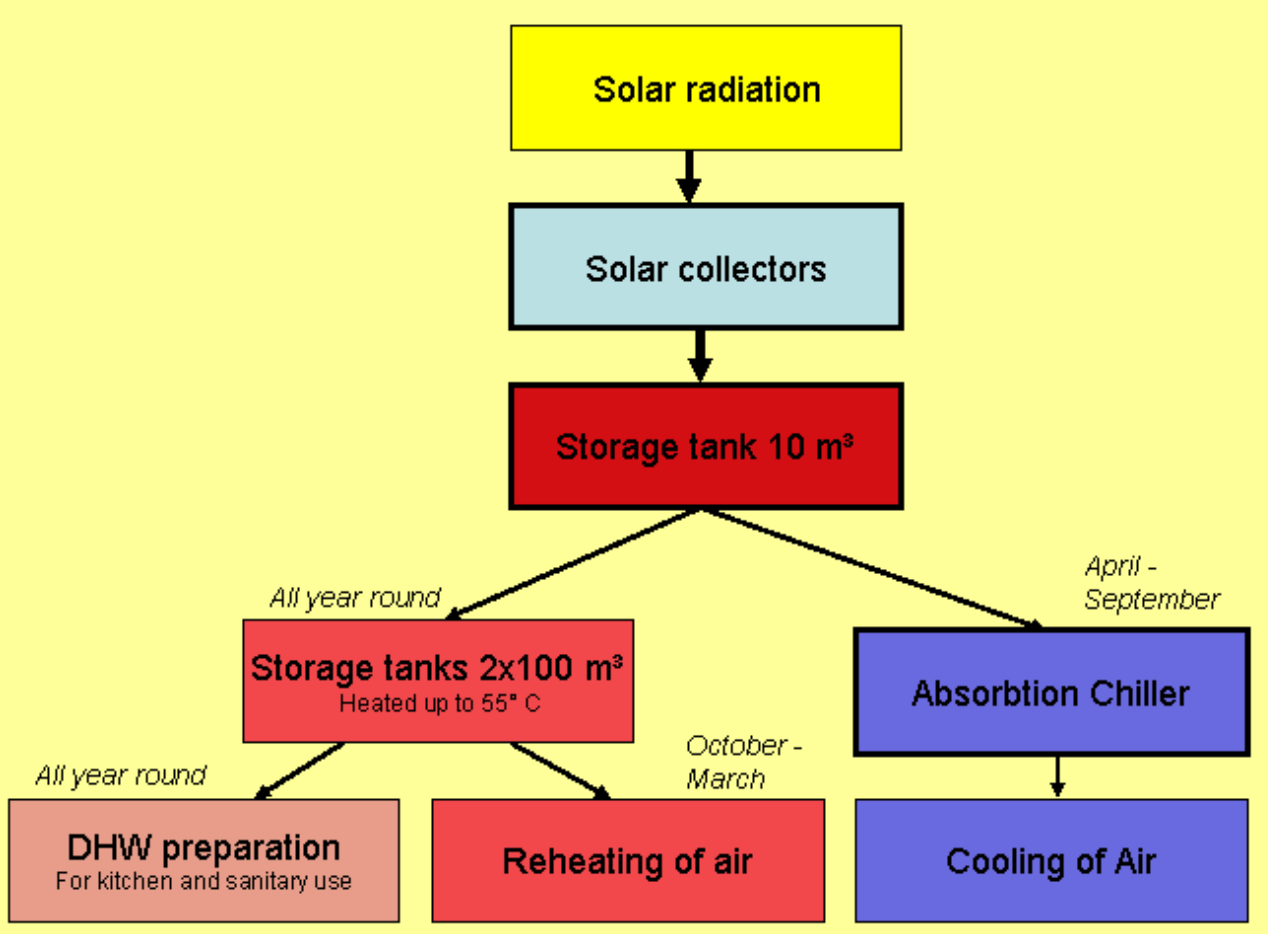

Figure 2. Flow chart on energy supply

\subsection{Technical details}

$\begin{array}{ll}\text { TOTAL SURFACE: } & 1,579 \mathrm{sqm} \\ \text { No. thermal collectors: } & \sim 112 \\ \text { SOLAR HEAT STORAGE: } & 10 \mathrm{~m}^{3} \\ \text { Capacity }\left[\mathrm{kW}_{\text {therm }} \text { ]: }\right. & 845 \\ \text { Capacity Absorption Chiller: } & 545 \mathrm{~kW}\end{array}$

Capacity Absorption Chiller: $545 \mathrm{~kW}$ 
Task 45 Large Systems

ESCo services, best practise example:

Caixa Geral de Depósitos, Lisbon, Portugal

IEA-SHC TECH SHEET 45.C.2.2A, page 4 of 7

\section{Energy production/savings}

\subsection{Total annual output/savings}

Solar thermal production: $\quad 978,2\left[\mathrm{MWh} /\right.$ year] $~ 619.5 \mathrm{kWh} / \mathrm{m}^{2}$

Substituted Energy:

Elctricity (heat pump and compression chiller)

Price of electricity:

$68[€ / \mathrm{MWh}]$

The total produced solar thermal energy is used locally.

\subsection{Yield for the applications}

Solar yield cold (cooling): $\quad 263 \mathrm{MWh} /$ year

Solar yield reheating:

202.6 MWh/year

Solar yield DHW:

$400 \mathrm{MWh} /$ year

\subsection{Energy distribution}

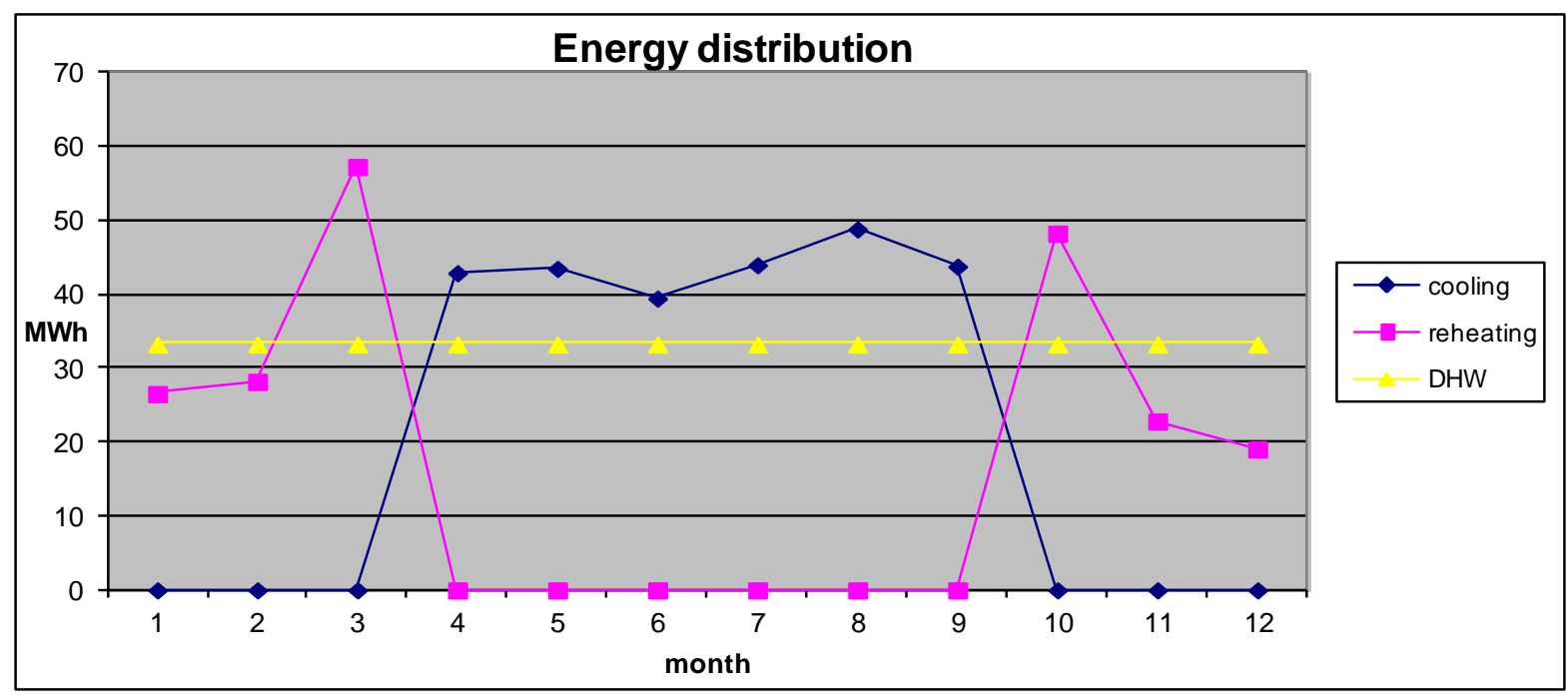

Figure 3. Monthly distribution of energy needed for the building

\subsection{Solar fractions}

The exact total consumption of the building are not known. Thus, the solar coverage can be roughly estimated.

Solar coverage:

- Cold: $8 \%$

- DHW: $\quad 40 \%$

- Reheating: $15 \%$ 
Task 45 Large Systems

ESCo services, best practise example:

\section{Business plan}

\subsection{Parameters of economic's simulation sale}

Economic parameters:

- Interest rate:

$6.0 \%$

- Grants:

$0 €$

- Maintenance and insurance cost: $6000 € /$ year

- Depreciation period: 25 years

- System's Depreciation charge: $4 \%$

- Cost increase fuel:

$6 \%$

From fig. 4 it is seen that:

- Payback time:

10.8 years

- IRR after 25 years:

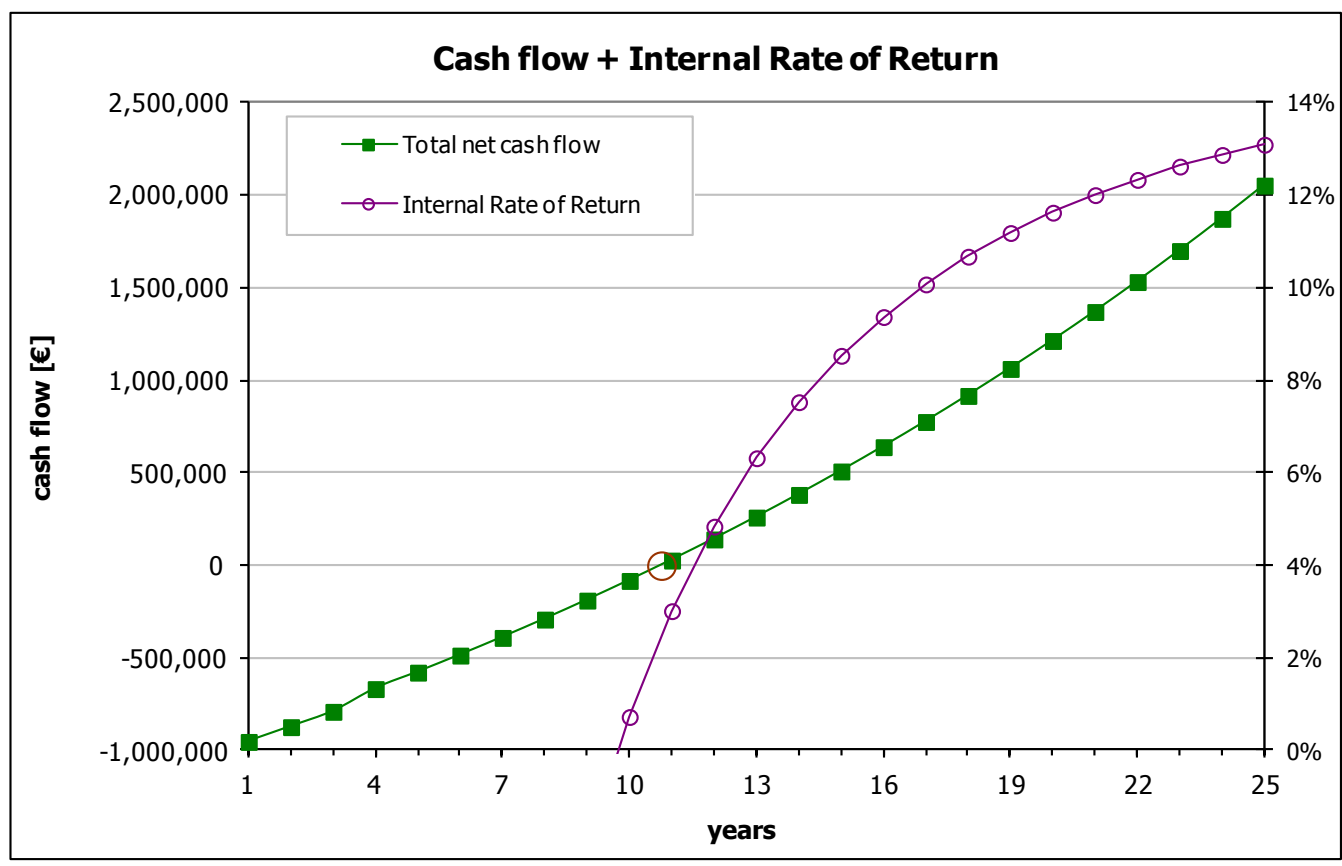

Figure 4. Cash flow and Internal rate of return

A comparison of the two cash flows for solar system (expenses) and electric energy savings results in the "Total net cash flow" in fig.5. 
Task 45 Large Systems

ESCo services, best practise example:

\section{Caixa Geral de Depósitos, Lisbon, Portugal}

IEA-SHC TECH SHEET 45.C.2.2A, page 6 of 7

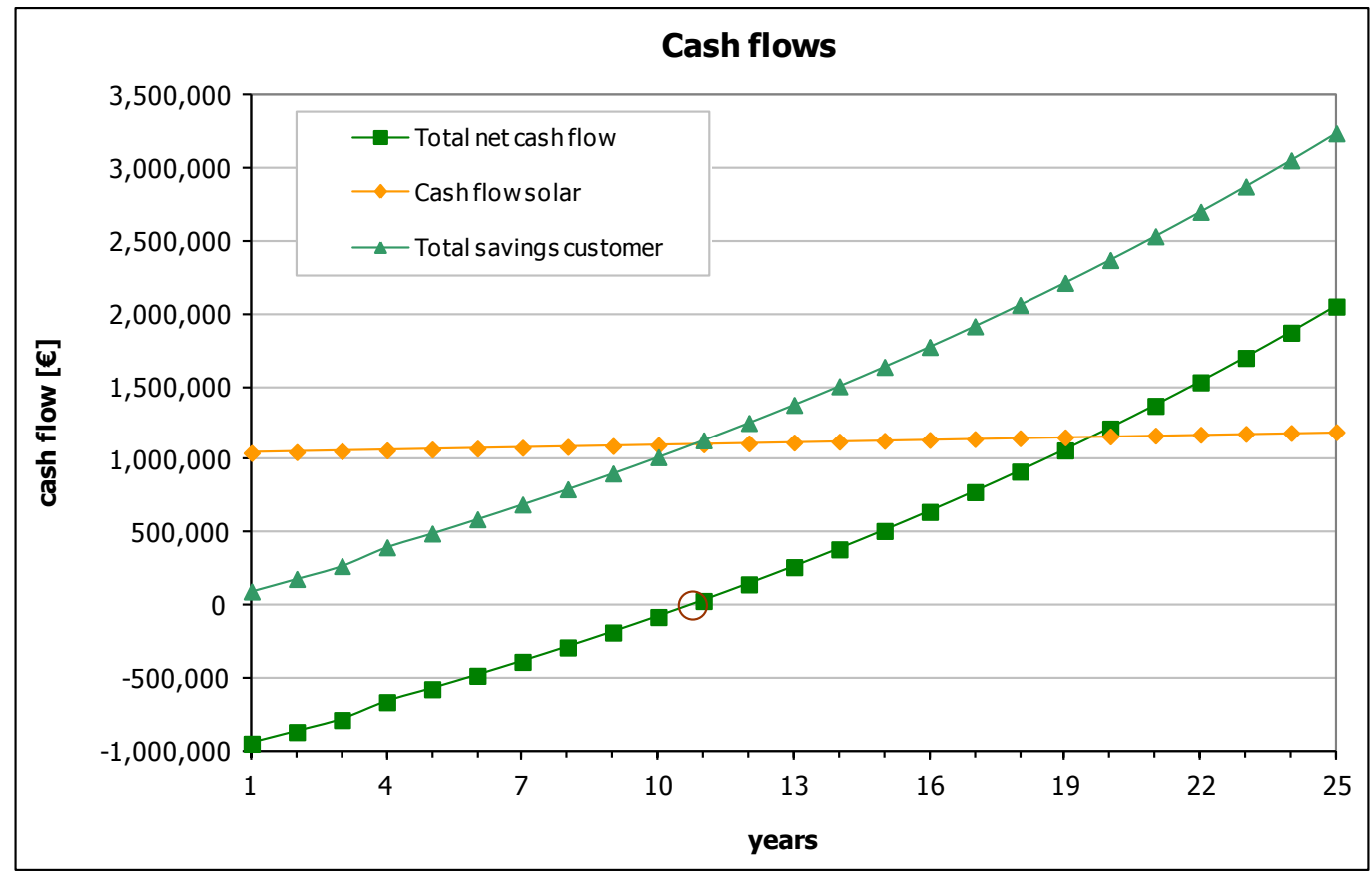

Figure 5. Cash flows

Total electricity savings: 1,252 MWh/year

\section{Environmental \& economic sustainability}

The measured total solar yields are shown in the table and figure below.

\begin{tabular}{|l|c|c|}
\cline { 2 - 3 } \multicolumn{1}{c|}{} & Total solar production & Total solar production \\
\cline { 2 - 3 } & {$[\mathrm{kWh} /$ month $]$} & {$\left[\mathrm{kWh} /\right.$ brutto $\mathrm{m}^{2}$ coll. $]$} \\
\hline January & 59,938 & 38.0 \\
\hline February & 61,594 & 39.0 \\
\hline March & 90,721 & 57.5 \\
\hline April & 94,736 & 60.0 \\
\hline May & 95,581 & 60.5 \\
\hline June & 89,823 & 56.9 \\
\hline July & 96,277 & 61.0 \\
\hline August & 103,228 & 65.4 \\
\hline September & 96,010 & 60.8 \\
\hline October & 81,676 & 51.7 \\
\hline November & 56,228 & 35.6 \\
\hline December & 52,434 & 33.2 \\
\hline SuM & 978,246 & 619.5 \\
\hline
\end{tabular}

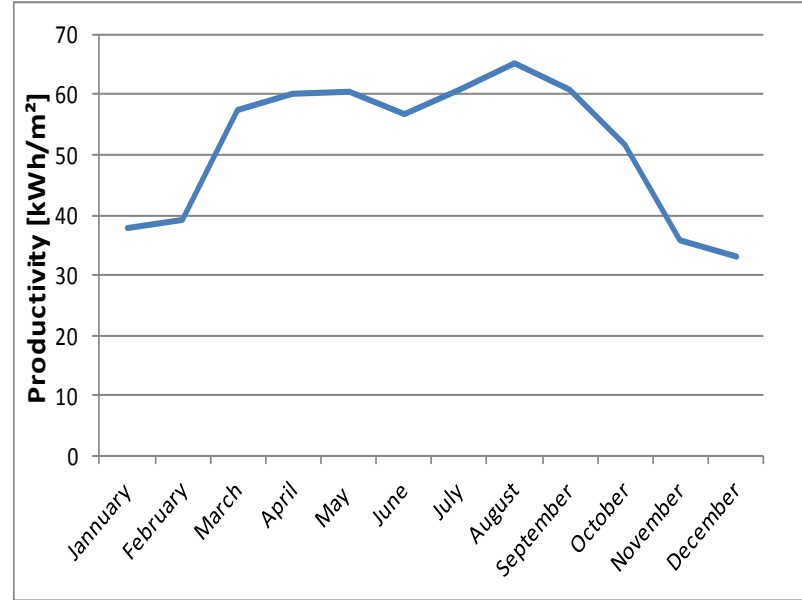

Figure 6. Table and plot of solar yields on monthly basis

Solar thermal energy is $\mathrm{CO} 2$-free and therefore environmentally friendly. In determining the $\mathrm{CO} 2$ savings following substituted heat source are considered: electricity. The impact of electricity amounts to $417 \mathrm{~kg}$ $\mathrm{CO} 2 / \mathrm{MWh}$ in Portugal. 
ESCo services, best practise example:

\begin{tabular}{|l|c|c|}
\hline \multicolumn{3}{|c|}{ Contribution to the environment } \\
\hline $\mathrm{CO}_{2}$ Savings & $\mathbf{4 0 7 , 9 2 8}$ & [tons $\mathrm{CO} /$ year] \\
\hline
\end{tabular}

Figure 7. Table showing the annual $\mathrm{CO}_{2}$ savings

Through this investment, the company is less dependent on electricity and unexpected energy price increases.

\section{Lessons learnt}

This solar thermal system shows us following points:

- Efficiency of a combined solar thermal system - cooling \& heating

- The peak of solar radiation and the peak demand of solar cooling match perfectly

- The solar yield depends strongly on the required temperature level of the application.

- Provided energy is often limited by available collector area.

- Often, an optimization of the existing system is possible by the integration of RES.

- Solar cooling cuts off electricity peaks and saves the most expensive electricity.

- Absorption Chillers have a long lifetime (> 25 years).

- Cooling load reduction (external loads) because of the mounted collectors on/in roof.

- Good economy also without grants.

Easy transferability to other office buildings. 